Int. J. Environ. Res. Public Health 2008, 5(2), 99-103

International Journal of

Environmental Research and Public Health

ISSN 1661-7827

www.ijerph.org

(c) 2008 by MDPI

\title{
Responses of Antioxidant Enzymes in Catfish Exposed to Liquid Crystals from E-Waste
}

\author{
Ran $\mathrm{An}^{1}$, Yadong $\mathrm{Li}^{2 *}$, Xiaojun $\mathrm{Niu}^{3}$ and Hongtao $\mathrm{Yu}^{1}$ \\ ${ }^{1}$ Department of Chemistry, Jackson State University, Jackson, MS 39217, USA \\ ${ }^{2}$ Department of Civil \& Environmental Engineering, Jackson State University, Jackson, MS 39217, USA \\ ${ }^{3}$ School of Environmental Science and Engineering, South China University of Technology, Guangzhou 510641, P. R. China \\ *Correspondence to Dr. Yadong Li. Email: yadong.li@jsums.edu
}

Received: 30 October 2007 / Accepted: 30 April 2008 / Published: 30 June 2008

\begin{abstract}
Liquid crystals (LCs) are typically elongated organic molecules with a non-uniform distribution of electrical charges leading to a dipole. LCs are widely used in displays of computers and other electronic devices. The rapid obsolescence rate of electronics results in large amounts of liquid crystal displays (LCDs) entering the environment. Data on health effects of LCs on living creatures are currently limited to some acute toxicity tests by a few major LC manufacturers. These tests concluded that the vast majority of LCs are not acutely toxic. Since the amount of LCs in electronic devices is very small, the health effects of LCs at low concentrations or doses become important. Catfish were used as the test animals in this study. Four major enzymes of the fish's antioxidant defense system catalase (CAT), superoxide dismutase (SOD), selenium-dependent glutathione peroxidase (Se-GPx), and glutathione-Stransferase (GST) were chosen as biomarkers to examine effects of LCs, which were taken from obsolete laptop personal computers made in the early 1990s. The catfish were fed with food containing different contents of LCs for 40 days. Activities of the four chosen enzymes in fish livers were assayed. The results showed that there were significant inductions of CAT, SOD, and Se-GPx activities in response to the LC doses. The plots of the enzyme activities versus LC doses suggested an occurrence of oxidative stress when the dose reached about $20 \mu \mathrm{g} \mathrm{LC} / \mathrm{g}$ fish·d. It was concluded that LCs can cause pollutant-induced stress to catfish at low doses. CAT, SOD and Se-GPx are effective biomarkers to give early warning on potential health effects of LCs on some aquatic lives including catfish.
\end{abstract}

Keywords: Liquid crystals, antioxidant enzyme, biomarker, E-waste, catfish

\section{Introduction}

As a new generation of display technology, the liquid crystal displays (LCDs) have increased dramatically on the market. The key materials in a LCD are liquid crystal (LC) compounds or liquid crystals (LCs). There are more than ten thousand LCs used in different LCDs, but information on the structure of the LCs is kept confidential between LC and LCD manufacturers. Therefore, studies on the effect of LCs on the environment have been mainly conducted by LC manufacturers. MERCK, the world's largest LC producer based in Germany, studied the acute oral toxicity on rats and aquatic living organisms, skin and eye irritation on rabbits, and mutagenic potential on bacteria of LC products of three world's leading LC manufacturers [1].
These tests were all short-term and high-dose (up to 2000 $\mathrm{mg} / \mathrm{kg}$ body weight). Based on the study, MERCK concluded that the LCs the companies put on the market are not harmful to living organisms. However, some studies have indicated that the absence of acute effect does not necessarily mean there is no chronic effect for the same contaminant [2-4]. Since the amounts of LCs in electronic devices are very small-approximately $0.6 \mathrm{mg} / \mathrm{cm}^{2}$ in a typical LCD, data on the effects of LCs at low concentrations or doses become important.

Living creatures have an antioxidant defense (AD) system which can neutralize the harmful effects of reactive oxygen species (ROS) including hydroxyl radicals $\left({ }^{\circ} \mathrm{OH}\right)$, superoxide radical anion $\left(\mathrm{O}_{2}^{-*}\right)$, and hydrogen peroxide $\left(\mathrm{H}_{2} \mathrm{O}_{2}\right)$. The $\mathrm{AD}$ system includes antioxidant enzymes 
catalase (CAT), superoxide dismutase (SOD), glutathione peroxidase (GPx), glutathione-S-transferase (GST), and other lower molecular weight substances such as glutathione (GSH), vitamins and proteins located in different tissues [5]. The antioxidant enzymes are found in almost all tissues of vertebrates, and their activities are especially high in the liver, a major organ responsible for the transformation of ROS. The ROS are generated during normal metabolism and the amounts are well-controlled under normal physiological conditions. When pollutants such as xenobiotic molecules enter the body, they undergo redox cycling and generate ROS. The body will produce more antioxidant enzymes to get rid of the undesired ROS. This response is also called induction of antioxidant enzymes. When the generation of ROS overwhelms the $\mathrm{AD}$ system, damages to lipids, proteins and DNA occur and this condition is referred to as oxidative stress $[6,7]$. The induction of the antioxidant enzymes gives an early warning on adverse health effects of certain pollutants on living organisms.

In this study, responses of the four major hepatic enzymes CAT, SOD, selenium-dependent GPx (Se-GPx), and GST of catfish's AD system exposed to LCs were tested to examine early effects of LCs at low doses.

\section{Materials and Methods}

\section{Test Animals}

Freshwater catfish of 80 days old were used as test animals. The average length and weight of the catfish were $8.0 \pm 0.3 \mathrm{~cm}$ and $22.0 \pm 0.2 \mathrm{~g}$, respectively. Catfish grow very slowly. It normally takes 2 to 4 years for a catfish to reach a weight of $500 \mathrm{~g}$. Catfish usually get food from the bottom of the water body. This is very suitable for this study because LCs are not soluble in water and normally adhere to detritus and sink to the bottom of the water body.

\section{Liquid Crystal Stock Solution}

LCs were collected from LCDs of laptop personal computers (IBM Thinkpad 390) made in the late 1990s. The LCDs used for this study were produced by SHARP, the main supplier of LCDs over that period of time. Laptops manufactured by Macintosh, Compaq, and Toshiba all used LCDs made by SHARP. The effective size of each LCD was $390 \mathrm{~cm}^{2}$. The amount of LCs sandwiched between the two thin glass layers was measured to be $0.23 \mathrm{~g}$ and the areal density of LCs in a LCD was calculated to be $0.60 \mathrm{mg} / \mathrm{cm}^{2}$. During the collection, each LCD was carefully separated into two glass layers. A total of 4 LCDs were used for LC collection. Each layer was wiped 10 times with a cotton ball wetted with dimethyl sulfoxide (DMSO). After each wipe, the liquid (LC-containing DMSO) in the cotton ball was squeezed into a container. About $30 \mathrm{~mL}$ of DMSO were in the beaker used for the cotton ball to be dipped after each wipe. After LC collection, the remaining DMSO in the beaker and the liquid in the other container were transferred into a volumetric flask and the total volume was adjusted to
$50 \mathrm{~mL}$ with fresh DMSO. The final concentration of LCs in DMSO was calculated to be $18 \mathrm{~g} / \mathrm{L}$. This was the LC stock solution for all the fish exposure tests.

\section{Fish Food}

Three different types of fish food were prepared for the test. One was the pure fish food purchased from a pet shop. It was in the form of dry pellets made from shrimps and other ingredients. The pure fish food was used for negative control. The second was DMSO-soaked fish food made by adding $32 \mathrm{~mL}$ of DMSO to $165 \mathrm{~g}$ pure fish food. It was used for blank control. The third was made by adding $32 \mathrm{~mL}$ of LC stock solution to $165 \mathrm{~g}$ of pure fish food. The content of LCs in this food was $3.5 \mathrm{mg} \mathrm{LC/g}$ food. This was called LC-containing food.

\section{Exposure Test}

Glass fish tanks of $37.8 \mathrm{~L}$ were used to accommodate the fish. The $\mathrm{pH}$ value of the water was $6.8 \pm 0.2$ and temperature $20 \pm 2^{\circ} \mathrm{C}$. The water in the tanks was constantly aerated. Each tank held 8 fish. The fish were first acclimated for 7 days. During this period, only the pure fish food was fed at $2.0 \mathrm{~g}$ per day per tank. To keep the water fresh, one-third of the water in each tank was replaced by newly prepared water every day after the fish had eaten up all the food. The total mortality of fish was zero during the 7 day acclimatization period.

After acclimatization, the fish were divided into 6 groups. Each group consisted of 8 fish in one fish tank. Group 1 was the negative control, fed with the pure fish food at $2.0 \mathrm{~g} / \mathrm{d}$. Group 2 was the LC-free blank control, fed with the DMSO-soaked fish food at $2.0 \mathrm{~g} / \mathrm{d}$. Groups 3, 4, 5 and 6 were fed with LC-containing food at $0.2,0.5,1.0$, and $2.0 \mathrm{~g} / \mathrm{d}$ respectively. The total food amount was made up to $2.0 \mathrm{~g} / \mathrm{d}$ by pure fish food for Groups 3, 4, and 5. For instance, Group 4 was fed with $0.5 \mathrm{~g} / \mathrm{d}$ of LC-containing food and $1.5 \mathrm{~g} / \mathrm{d}$ of pure fish food. This exposure test lasted for $40 \mathrm{~d}$. Other similar studies used exposure periods of $2,4,7,14,21,28$, and $40 \mathrm{~d}[3-4,8-10]$.

\section{Sample Preparation}

After the 40 day exposure, all fish were weighed and dissected. The livers were taken out and rinsed by physiological salt water. About $0.30 \mathrm{~g}$ of liver tissue from each fish was homogenized in $3 \mathrm{~mL}$ of $10 \mathrm{mM}$ Tris buffer ( $\mathrm{pH}$ 7.5) which contained $0.01 \mathrm{M}$ Tris, $0.25 \mathrm{M}$ sucrose, and $0.01 \mathrm{M}$ EDTA. The homogenized solution was centrifuged at $10,000 \mathrm{rpm}$ at $4^{\circ} \mathrm{C}$ for $10 \mathrm{~min}$. The supernatant solution was called enzyme solution. It was stored at $-80^{\circ} \mathrm{C}$ for further analysis of protein content and activities of four antioxidant enzymes.

\section{Sample Analysis}

The total protein content of the enzyme solution of each fish liver was determined according to the method by 
Bradford [11]. A G-250 solution was prepared by adding $100 \mathrm{mg}$ Coomassie Brilliant Blue into $50 \mathrm{~mL}$ of $95 \%$ ethanol and $100 \mathrm{~mL}$ of $85 \%$ phosphoric acid, and diluted with distilled water to $1,000 \mathrm{~mL}$. A volume of $10 \mu \mathrm{L}$ of the enzyme solution was added into $5 \mathrm{~mL}$ of the G-250 solution. The absorbance at $595 \mathrm{~nm}$ was measured by a spectrophotometer to determine the protein content. The calibration curve was established by standard bovine serum albumen (BSA) solutions of 0, 50, 100, 200, 300, 400, and $500 \mu \mathrm{g} / \mathrm{mL}$.

CAT activity was determined by the method of Xu et al. [12]. This method is based on the first-order reaction of CAT with $\mathrm{H}_{2} \mathrm{O}_{2}$. A $10 \mu \mathrm{L}$ enzyme solution was added to $3.0 \mathrm{~mL} \mathrm{H}_{2} \mathrm{O}_{2}$-phosphate buffer solution and the absorbance of $\mathrm{H}_{2} \mathrm{O}_{2}$ at $250 \mathrm{~nm}$ was measured every $5 \mathrm{~s}$ for $60 \mathrm{~s}$ by a spectrophotometer. The $\mathrm{H}_{2} \mathrm{O}_{2}$-phosphate buffer solution was made by diluting $0.16 \mathrm{~mL} \mathrm{H} \mathrm{O}_{2}(30 \% \mathrm{w} / \mathrm{v})$ to $100 \mathrm{~mL}$ with a $67 \mathrm{mM}$ phosphate buffer $(\mathrm{pH}=7.0)$. The phosphate buffer was made by dissolving $3.522 \mathrm{~g} \mathrm{KH}_{2} \mathrm{PO}_{4}$ and 7.268 g $\mathrm{Na}_{2} \mathrm{HPO}_{4} \cdot \mathrm{H}_{2} \mathrm{O}$ into $1000 \mathrm{~mL}$ pure water. The reference cell was filled with this phosphate buffer alone. One unit of CAT activity (U) was defined as $1 U=100 \mathrm{~K} / \mathrm{ln} 2$, where $K$ is the slope of the curve $\ln A$ versus time and $A$ is the absorbance at $250 \mathrm{~nm}$.

SOD activity was determined according to the method by Zhu et al. [13]. This method was based on inhibition of SOD by auto-oxidation of 1,2,3-benzenetriol. First, the autooxidation rate $\left(K_{o}\right)$ of 1,2,3-benzenetriol in $0.05 \mathrm{M}$ Tris- $\mathrm{HCl}$ buffer solution $(\mathrm{pH}=8.2)$ was determined by spectrophotometry at $325 \mathrm{~nm}$. Then the SOD-inhibited autooxidation rate $\left(K_{S O D}\right)$ was measured by adding $10 \mu \mathrm{L}$ enzyme solution to the same buffer solution. One unit of SOD activity $(\mathrm{U})$ is defined as the quantity of enzyme protein used to inhibit $50 \%$ of the auto-oxidation rate of $1,2,3-$ benzenetriol at $25^{\circ} \mathrm{C}$. It was calculated as $1 \mathrm{U}=\left(\mathrm{K}_{o^{-}}\right.$ $\left.K_{S O D}\right) /\left(3.1 \times K_{d} / 2\right)$.

Se-GPx was assayed according to the method by Hafeman [14] with slight modification by Zhang et al. [8]. This method is based on the theory that Se-GPx can catalyze the reaction between GSH and peroxides. The remaining amount of GSH in the reaction can indicate the activity of Se-GPx. The remaining GSH was determined by adding 5,5'-dithio-bis-2-nitrobenzoic acid (DTNB) at $37^{\circ} \mathrm{C}$, which reacts with GSH to produce 5-thio-2-nitrobenzoic acid anion. This product has a maximum absorbance at 412 $\mathrm{nm}$. The absorbance is proportional to the amount of remaining GSH and inversely proportional to the activity of Se-GPx. Since GSH can react with $\mathrm{H}_{2} \mathrm{O}_{2}$ without the existence of Se-GPx, the reduction of GSH caused by nonenzyme reaction was deducted in the calculation. One unit of Se-GPx activity (U) was defined as the amount of enzyme that oxidizes $1 \mu \mathrm{mol} / \mathrm{L}$ of GSH per min.

GST activity was determined by the method of Habig et al. [15]. A reaction mixture containing $2.8 \mathrm{~mL}$ phosphate buffer (pH=6.5), $0.5 \mathrm{~mL}$ of $20 \mathrm{mM}$ GSH water solution and $50 \mu \mathrm{L}$ enzyme solution was prepared at $25^{\circ} \mathrm{C}$. Then 100 $\mu \mathrm{L}$ of $30 \mathrm{mM}$ 1-chloro-2,4-dinitrobenzene (CDNB) ethanol solution was added for conjugation of GST with CDNB.
After 3 min reaction, $0.3 \mathrm{~mL}$ of $33 \%$ trichloroacetic acid (TCA) was added to terminate the reaction. The mixture was centrifuged at 3,000 rpm for $5 \mathrm{~min}$. The supernatant was collected and the GST activity was determined by the change of optic density (OD) or absorbance at $340 \mathrm{~nm}$ as compared to that of the same mixture into which CDNB and TCA were added at the same time (no conjugation). One unit of GST activity (U) was expressed as the amount of enzyme necessary to conjugate $1 \mu \mathrm{mol}$ of CDNB per min.

Finally, all enzyme activity data were normalized by the total protein content in the livers and were expressed as units of activity per mg of protein (U/mg Pr).

\section{Results and Discussion}

Doses of Test Groups

During the $40 \mathrm{~d}$ test period, there was no appreciable amount of growth in the body weight of the catfish. The LC doses for Groups 1 through 6 were calculated to be 0,0 , 4.0, 10, 20, and $40 \mu \mathrm{g} \mathrm{LC/g}$ fish.d, respectively. Following is a sample calculation of the LC dose for Group 3 to which $0.2 \mathrm{~g} / \mathrm{d}$ of LC-containing food was fed.

$\frac{3.5 \mathrm{mgLC} / \mathrm{g} \times 0.2 \mathrm{~g} / \mathrm{d}}{22 \mathrm{~g} / \text { fish } \times 8 \text { fish }}=4.0 \times 10^{-3} \mathrm{mgLC} / \mathrm{g}$ fish $d=4.0 \mu \mathrm{g} \mathrm{LC} / \mathrm{g}$ fish $d$

The responses of the activities of the four antioxidant enzymes in catfish livers of the six test groups to LC doses are shown in Figures 1 to 4 . The error bars in all the graphs represent the confidence limits for $95 \%$ confidence level from the data for each group. Statistical differences among group means were determined using the one-way ANOVA. The differences between any dose group and the negative control group or between any two dose groups were assessed using Student's t-test. The differences were considered statistically significant when $\mathrm{p}<0.05$.

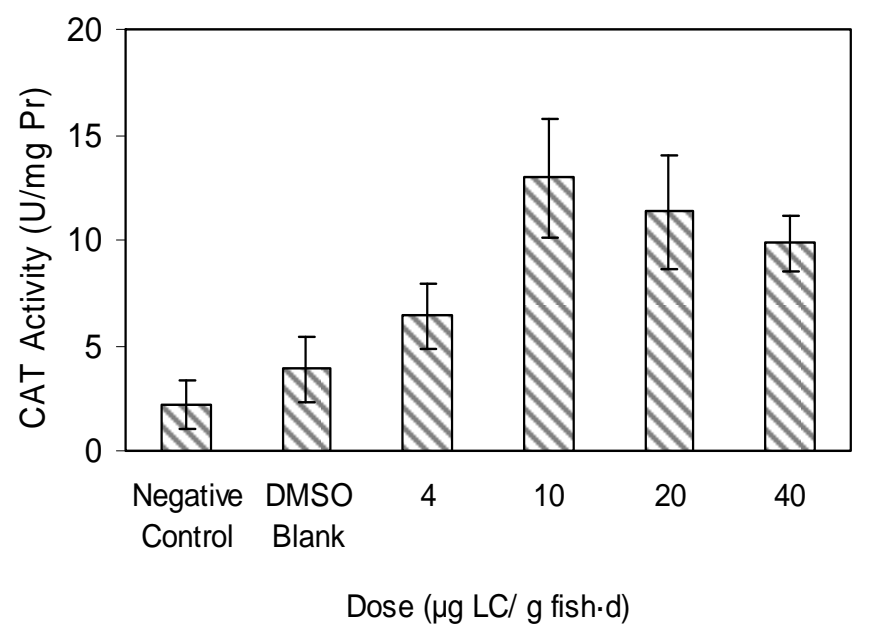

Figure 1: Response of CAT activity in fish livers to LC dose 
Clear induction of CAT activity was observed with the increase of LC dose (Figure 1). Statistical differences among the data for all groups were significant $(p<0.01$, ANOVA). The differences between any one of the four dose groups and the negative or the DSMO blank control were also significant $(\mathrm{p}<0.05$, t-test). Difference was not significant between the negative control and DMSO blank control ( $>0.1$, t-test). CAT activity reached a peak between 10 and $20 \mu \mathrm{g} \mathrm{LC} / \mathrm{g}$ fish.d, then started to decrease with LC dose increasing to $40 \mu \mathrm{g} \mathrm{LC/g}$ fish.d. While the difference between the 10 and $20 \mu \mathrm{g} \mathrm{LC} / \mathrm{g}$ fish $\cdot \mathrm{d}$ dose groups was not significant ( $>0.4$ ), the $40 \mu \mathrm{g} \mathrm{LC/g}$ fish $\cdot d$ dose group differed significantly from the $10 \mathrm{LC} / \mathrm{g}$ fish.d dose group $(\mathrm{p}<0.05$, t-test). Compared to the negative control, SOD activities for all the dose groups were induced significantly $(\mathrm{p}<0.05$, t-test $)$. A significant response of SOD activity to the DMSO blank control (Figure 2) was observed $(\mathrm{p}<0.001)$, indicating that DMSO solvent could cause induction of this enzyme. The activity of SOD peaked around $20 \mu \mathrm{g} \mathrm{LC/g}$ fish.d and decreased slightly at $40 \mu \mathrm{g} \mathrm{LC/g}$ fish.d. However, the differences among the 10,20 , and $40 \mu \mathrm{g} \mathrm{LC} / \mathrm{g}$ fish $\cdot \mathrm{d}$ dose groups were insignificant ( $p>0.70$, ANOVA).

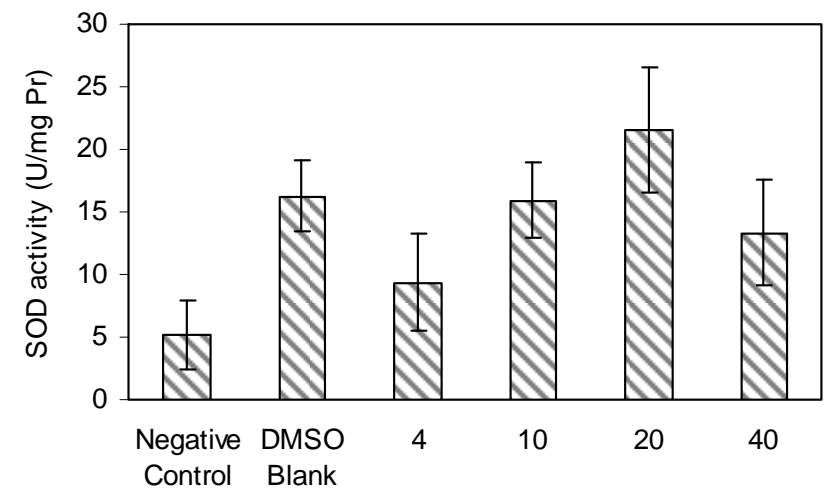

Dose ( $\mu \mathrm{g} \mathrm{LC/g}$ fish.d)

Figure 2: Response of SOD activity in fish livers to LC dose

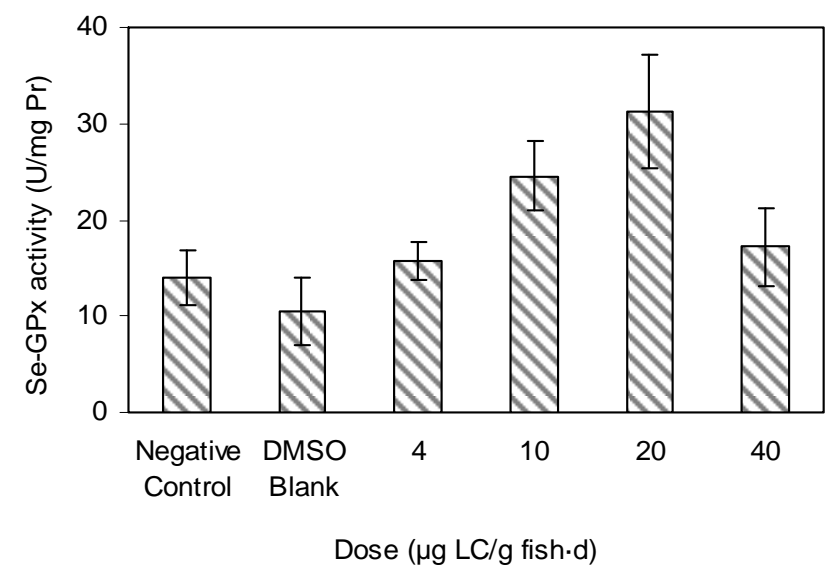

Figure 3: Response of Se-GPx activity in fish livers to LC dose
For Se-GPx, its activity was not significantly induced until the LC dose reached $10 \mu \mathrm{g} \mathrm{LC} / \mathrm{g}$ fish.d. It peaked around $20 \mu \mathrm{g} \mathrm{LC/g}$ fish.d (Figure 3) and dropped significantly at $40 \mu \mathrm{g} \mathrm{LC/g}$ fish.d $(\mathrm{p}<0.05$, t-test for 20 and 40 dose groups). The increase of antioxidant enzyme activities at lower LC doses suggests a compensatory response to a pollutant-induced stress. When the LC dose exceeded the compensatory threshold, oxidative stress may have occurred and the compensatory mechanism started to fail. The activity of GST did not show significant changes with all the LC doses ( $p=0.90$, ANOVA), suggesting that GST may not be involved in the metabolism of these chemicals. Several other studies also reported that GST's response to some pollutants was insignificant $[8,16,17]$.

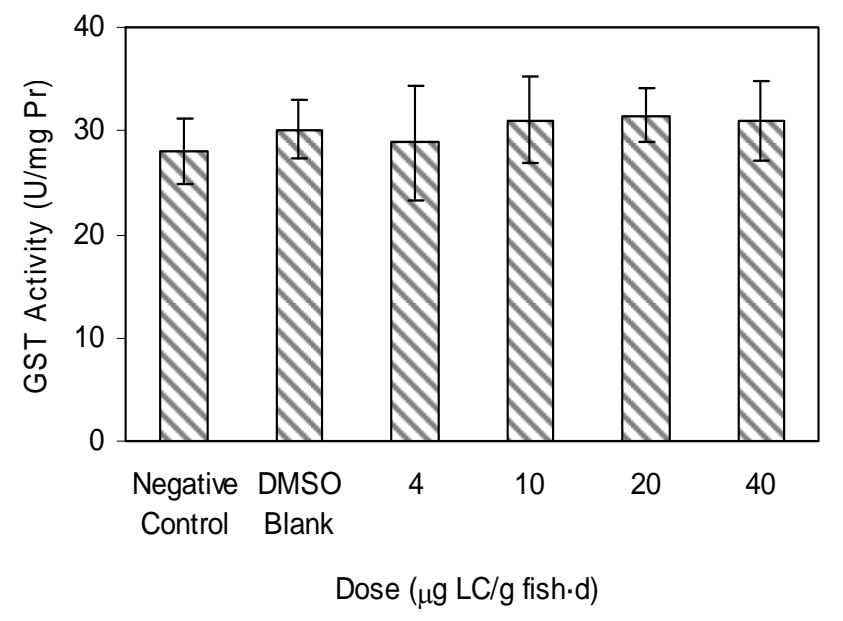

Figure 4: Response of GST activity in fish livers to LC dose

\section{Conclusions}

The results presented here show significant responses of the activities of three selected hepatic enzymes CAT, SOD, and Se-GPx to LC dose. These enzymes can be potential biomarkers for early warning of adverse health effects of LCs on some aquatic lives including catfish. The response patterns suggest that antioxidant enzymes are induced when catfish are exposed to low doses of LCs. When the LC dose reached about $20 \mu \mathrm{g} \mathrm{LC} / \mathrm{g}$ fish.d, oxidative stress occurred. The LCs contained in LCDs of obsolete electronic devices such as laptop personal computers manufactured in the early 1990s may have adverse health effects on aquatic lives at fairly low concentrations. Proper handling and disposal of LCDcontaining electronic waste is essential for the preservation of a healthy environment. Further comprehensive studies on the chronic toxicity of LCs on other living creatures and human beings are necessary.

Acknowledgment: This research was supported by a grant from the National Science Foundation (Grant No. BES0238765). 


\section{References}

1. Werner, B.; Simon-Hettich, B.; Hoenicke, P.: Toxicological and Ecotoxicological Investigations of Liquid Crystals. MERCK, http://www.MERCK.com, 2002

2. Geracitano, L.; Monserrat, J. M.; Bianichini, A.: Physiological and antioxidant enzyme responses to acute and chronic exposure of Laeonereis acuta (Polychaeta, Nereididae) to copper. J. Exp. Marine Biol. Ecol., 2002, 277, 145-156

3. Webb, N. A.; Shaw, J. R.; Moran, J.; Hogstrand, C.; Wood, C. M.: Acute and Chronic physiological effects of silver exposure in three marine teleosts. Aquat. Toxicol, 2001, 54, 161-178

4. Ronisz, D.; Finne, E. F.; Karlsson, H.; Forlin, L.: Effects of HBCDD and TBBPA on hepatic enzymes and other biomarkers in juvenile rainbow trout and feral eelpout. Aquat. Toxicol., 2004, 69, 229-245

5. Frei, B.: Molecular and biological mechanisms of antioxidant action. FASEB J., 1999, 13, 963-964

6. Di Guilio, R. T.; Washburn, P. C.; Wenning, R. J.; Winston, G. W.; Jewell, C. S.: Biochemical responses in aquatic animals: a review of determinants of oxidative stress. Environ. Toxicol. Chem., 1989, 8, 1103-1123

7. Storey, K. B.: Oxidative stress: animal adaptations in nature. Braz, J. Med. Biol. Res., 1996, 29, 1715-1733

8. Zhang, J.; Shen, H.; Wang, X.; Wu, J.; Xue, Y.: Effects of chronic exposure of 2,4-dichlorophenol on the antioxidant system in liver of freshwater fish Carassius auratus. Chemoshpere, 2004, 55, 167-174

9. Pedrajas, J. R.; Lopez-Barea, J.; Peinado, J.: Dieldrin induces peroxisomal enzymes in fish (sparus aurata) liver. Comp. Biochem. Physiol., 1996, 115C, 125-131

10. Wijeyaratne, W. M. D. N.; Pathiratne, A: Acetylcholinesterase inhibition and gill lesions in Rasbora caverii, and indigenous fish inhabiting ric field associated waterbodies in Sri Lanka. Ecotoxicology, 2006, 15, 609-619

11. Bradford M. M.: A rapid and sensitive method for the quantitation of microgram quantities of protein utilizing the principle of protein-dye binding. Anal. Biochem., 1976, 72, 248-254

12. Xu, J.; Yuan, X.; Lang, P.: Determination of catalase activity and catalase inhibition by ultraviolet spectrophotometry. Chin. Environ. Chem., 1997, 16, 73-76

13. Zou, G.; Gui, X.; Zhong, X.; Zhu, R.: A new method for SOD activity measurement. Prog. Biochem. Biophy. (in Chinese), 1986 ,4, 71-73

14. Hafeman, D. G.; Sunde, R. A.; Hoekstra, W. G.: Effect of dietary selenium and erythrocyte and liver glutathione peroxidase in the rat. J. Nutrit., 1973,104, 580

15. Habig, W. H.; Pabst, M. J.; Jakoby, W. B.: Glutathione S-transferases: the first step in mercapturic acid formation. J. Biol. Chem., 1974, 249, 7130-7139

16. Rendon-von Osten, J.; Ortiz-Arana, A.; Guilhermino, L.; Soares, A.: In vivo evaluation of three biomarkers in the mosquitofish exposed to pesticides. Chemosphere, 2005, 58, 627-636

17. Van Erp, S.; Brooth, L.; Gooneratne, R.; O’Halloran, K.: Sublethal responses of wolf spiders to organophosphorous insecticides. Environ. Toxicol., 2002, 7, 449-456 